\title{
Implementasi Forward Chaining Pada Sistem Pakar Sebagai Basis Informasi Persebaran Penyakit Padi
}

\author{
Rodianti $^{* 1}$, Yenni Fatman,S.T.,M.T. ${ }^{2}$, Isbandi,S.T.,M.M.,M.T. ${ }^{3}$, Dr.Rahmini,S.Si.,M.Si. ${ }^{4}$, Laila \\ Nur,S.P. ${ }^{5}$ \\ ${ }^{1,2,3}$ Program Studi Teknik Informatika, Fakultas Teknik Universitas Islam Nusantara; Alamat: \\ Jl.Soekarno Hatta No.530, Sekejati,Kec.Buah Batu, Kota Bandung, Jawa Barat 40286 \\ ${ }^{4,5}$ Balai Besar Penelitian Tanaman Padi (BB Padi); Alamat: Jl.Raya 9, Tromol Pos 11, \\ Cikampek Subang, Jawa Barat 41258 \\ e-mail: *11anarodianti20@gmail.com, ${ }^{2}$ yennifatman123@gmail.com, ${ }^{3} 4$ isbandi@gmail.com, \\ a.rahmini@gmail.com,
}

\begin{abstract}
Abstrak
Penduduk Indonesia sebagian besar mengkonsumsi makanan pokok yang berasal dari tanaman padi (Oriza sativa L). Gagal panen bisa terjadi pada tanaman padi, penyebab gagal panen salah satunya adalah penyakit tanaman padi. Setiap penyakit pada umumnya memiliki gejala yang menunjuk kepada penyakit itu sendiri, gejala tersebut dapat dikenali dengan dilakukan pendiagnosaan. Karena kurangnya pengetahuan petani dan terbatasnya pakar disuatu daerah untuk melakukan pendiagnosaan penyakit, maka sistem ini hadir memberikan solusi untuk alternatif diagnosa penyakit tanaman padi. Dalam hal ini mengimplementasikan sistem pakar dengan metode forward chaining guna mendapatkan temuan penyakit padi hasil dari diagnosa, selain itu pada sistem pakar ini akan mengetahui informasi geografis persebaran penyakit tanaman padi secara real time dengan pengambilan lokasi pengguna disuatu daerah. Diagnosa Penyakit tanaman padi dengan sistem pakar ini merupakan Aplikasi yang berbasis web menggunakan framework Laravel dan untuk penyimpanan data menggunakan MySQL. Pada pengujian yang telah dilakukan oleh pakar mendapatkan nilai akurasi sebesar $100 \%$.
\end{abstract}

Kata kunci-Sistem pakar, Metode Forward Chaining, Informasi georafispersebaran penyakit tanaman padi

\begin{abstract}
Most of the Indonesian population consume staple foods derived from the rice plant (Oriza sativa L). Harvest failure can occur in rice plants, one of the causes of crop failure is rice plant disease. Every disease in general has symptoms that point to the disease itself, these symptoms can be recognized by doing a diagnosis. Due to the lack of knowledge of farmers and limited experts in an area to diagnose diseases, this system is here to provide solutions for alternative diagnoses of rice plant diseases. In this case, implementing an expert system with the forward chaining method in order to obtain rice disease findings from the diagnosis, besides that this expert system will find out geographic information on the distribution of rice plant diseases in real time by taking the user's location in an area. Diagnosis of rice disease with this expert system is a web-based application using the Laravel framework and for data storage using MySQL. In the tests that have been carried out by experts, the accuracy value is $100 \%$.
\end{abstract}

Keywords - Expert system, Forward Chaining Method, Georaphysical information on the spread of rice plant diseases 


\section{PENDAHULUAN}

$\mathrm{N}$ egara agraris adalah negara yang penduduknya sebagian besar berprofesi sebagai petani, salah satu diantaranya adalah Negara Indonesia. Negara indonesia merupakan salah satu negara yang memiliki komoditas potensial pertanian. Pertanian di Indonesia memegang peran penting dari keseluruhan perekonomian nasional, bisa dilihat dari sektor pertanian masih menjadi andalan penciptaan lapangan pekerjaan dalam jumlah yang cukup besar dibandingkan dengan sektor lainnya dalam perekonomian indonesia [1].

Komoditas potensial pertanian di Indonesia salah satunya adalah tanaman padi. Tanaman padi (Oriza Sativa L) adalah tanaman makanan pokok bagi sebagian besar penduduk di Indonesia. Padi dapat ditanam dilahan kering maupun lahan basah. Sawah berperan dominan terhadap produksi padi karena pada umumnyapadi ditanam di lahan basah [2].

Salah satu penyebab gagal panen adalah penyakit pada padi, Penyakit pada padi ini memberikan kerugian yang besar bagi para petani karena berdampak merusak tanaman sehingga terjadi kegagalan panen. Pada setiap penyakit tersebut selalu di awali dengan gejala - gejala yang diderita sebelumnya sampai gejala nya mencapai tahap yang lebih parah dan meluas. Gejala - gejala tersebut dapat dikenali terlebih dahulu sebelum meluas parah dengan melakukan pendiagnosisan terlebih dahulu sehingga dapat di kendalikan penyakitnya lebih cepat. [3].

Pendiagnosaan penyakit pada padi sangat penting untuk dilakukan sejak dini, karena jika tidak dilakukan maka penyakit pada padi akan cepat menyebar luas. Dalam pendiagnosisan penyakit pada tanaman padi dibutuhkan seorang pakar dalam penanganan. Mengatahui gejalagejala yang ditimbulkan akan menentukan penyakit serta mendapatkan pengendalian penyakit pada tanaman padi, akan tetapi hal itu sulit dikarenakan terbatasnya pakar disuatu daerah sebagai sarana untuk berkonsultasi untuk mengetahui pengendalian pada penyakit yang menjangkit tanaman padi.

Maka dibutuhkan alternatif berupa media konsultasi yang mudah diakses, hasil dan saran sesuai dengan seorang pakar untuk membantu permasalahan petani dalam mengenali penyakit pada tanaman padi. Perangkat handphone atau telepon genggam yang biasa di sebut ponsel merupakan alat telekominukasi yang mempunyai kemampuan dasar yang sama dengan telepone konvensional namun dapat di bawa kemana pun (Portabel,Mobile) [4]. Maka handphone mampu menjadi perangkat dalam menunjang penggunaan sistem pakar sebagai media konsultasi diagnosa penyakit tanaman padi.

Sistem pakar (expert system) adalah sebuah ilmu yang dapat mengadopsi pengetahuan manusia ke dalam sebuah sistem komputer, sehingga komputer dapat menyelesaikan permasalahan - permasalahan yang dilakukan oleh seorang pakar (expert). Dalam melakukan perancangan sistem pakar dikatakan baik jika dapat menyelesaikan permasalah tertentu dengan dengan meniru cara kerja dari pakar (expert). Salah satu Metode yang digunakan dalam sistem pakar adalah Metode Forward chaining. Metode Forward chaining merupakan salah satu metode penalaran yang dimulai dari fakta untuk mendapatkan sebuah kesimpulan dari fakta tersebut. Penalaran dimulai dari fakta terlebih dahulu yang selanjutnya mendapatkan kebenaran hipotesis [5].

Dalam hal ini, akan dilakukan implementasi menggunakan metode forward chaining pada sistem pakar sebagai basis informasi geografis persebaran penykait tanaman padi menggunakan framework Laravel untuk pembuatannya sedangkan untuk penyimpanan data gejala dan penyakit menggunakan MySQL.

Beberapa penelitian sebelumnya yang relevan dengan penelitian ini adalah penelitian yang dilakukan oleh Robby Rizky dengan judul "Implementasi metode Forward Chaining untuk diagnosa penyakit Covid-19 di RSUD Berkah Pandeglang Banten". Penelitian ini menggunakan sistem runut maju yang akan mendeteksi setiap gejala yang dialami pasien [6]. Penelitian lainnya yang dilakukan oleh Ilham Roni Yansyah dengan judul "Sistem pakar metode 
Forward Chaining untuk mengukur keparahan penyakit gigi dan mulut", dalam hal ini peneliti mempresentasikan rule atau kaidah dari 27 fakta gejala dan 8 penyakit yang dipaparkan oleh pakar, hasil dari pengujian metode ini adalah sebanyak 10 data pasien yang didiagnosa mendapatkan hasil 8 sama dengan analisis dokter sehingga tingkat akurasinya sebesar $80 \%$ [7]. Penelitian selanjutnya dengan judul "Sistem pakar diagnosa penyakit tanaman kedelai menggunkan metode forward chaining berbasis Web", tujuan dari penelitian ini adalah untuk mngetahui penyakit apa saja yang menyerang tanaman kedelai dengan mudah tanpa harus mengeluarkan biaya yang banyak untuk konsultasi kepada pakar [8].

Implementasi metode forward chaining pada sistem pakar terlebih dahulu mencari sebuah informasi yang ada dan penggabungan rule untuk menghasilkan suatu kesimpulan. Hasil dari penelitian ini digunakan untuk mendiagnosa jenis penyakit, cara penyebaran penyakit, cara pengendalian terhadap penyakit tanaman padi kemudian selain itu akan mengetahui informasi persebaran penyakit pada tanaman padi yang diambil dari koordinat lokasi input data pengguna.

\subsection{Tinjauan Pustaka}

\section{METODE PENELITIAN}

\subsubsection{Sistem Pakar}

Sistem pakar adalah suatu program komputer yang dirancang untuk memodelkan kemampuan penyelesaian masalah yang dilakukan oleh seorang pakar [14]. Gambar dibawah ini merupakan gambar struktur sistem pakar

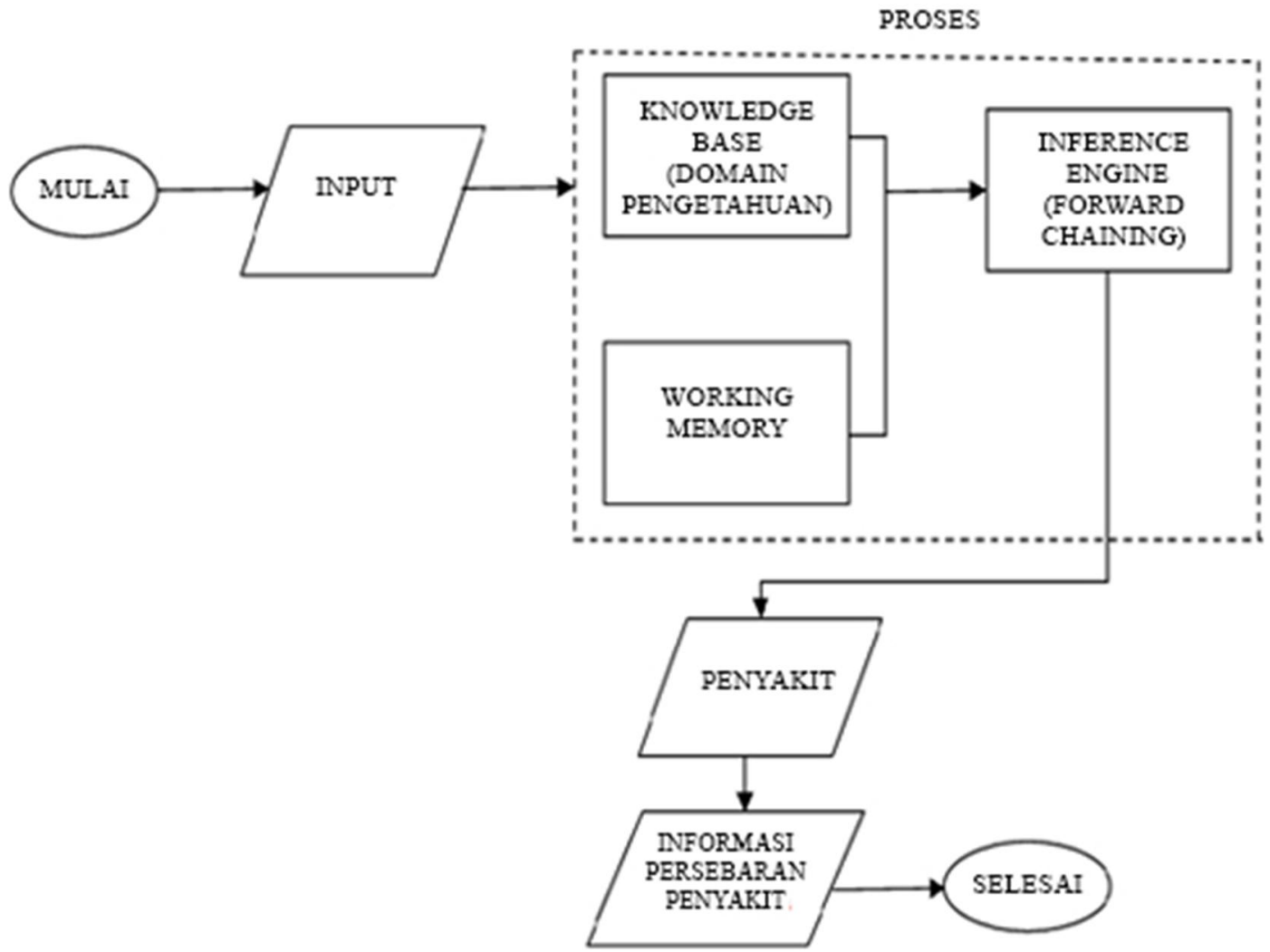

Gambar 1. Struktur Sistem Pakar 
Berikut penjelasan gambaran umum sistem:

1. Input, merupakan pertanyaan-pertanyaan yang muncul dalam aplikasi sistem pakar

2. Knowledge base (Domain Pengetahuan), pengetahuan mengenai penyakit yang dijadikan sebagai rule-based.

3. Working memory, fakta-fakta yang diinputkan oleh pengguna kedalam aplikasi sistem pakar.

4. Inference engine, proses pencocokan fakta-fakta yang ada pada working memory dengan domain pengetahuan, untuk menarik kesimpulan dari masalah yang dihadapi.

5. Klasifikasi penyakit, hasil kesimpulan dari proses diagnosa sistem pakar

6. Basis Informasi geografis mengenai persebaran penyakit hasil input sistem pakar oleh pengguna [9].

\subsubsection{Sistem Informasi Geografis (GIS)}

SIG adalah sistem komputer yang digunakan untuk mengumpulkan, memeriksa, mengintegrasikan dan menganalisa informasi-informasi yang berhubungan dengan permukaan bumi. Pada dasarnya, istilah sistem informasi geografis merupakan gabungan dari tiga unsur pokok yaitu sistem, informasi dan geografis [2].

\subsubsection{Metode forward Chaining}

Metode forward chaining yaitu sebuah pencarian yang dimotori data (data driven search). Dimana pencarian dimulai dari premis - premis atau informasi masukan (if) terlebih dahulu yang kemudian menuju ke konklusi atau drived information (then). Forward chaining menggunakan himpunan kondisi aksi. Metode Forward chaining menggunakan data untuk menentukan aturan mana yang dijalankan atau menambahkan sebuah data ke proses memori kerja sehingga di temukan sebuah hasil. Metode forward chaining ini bisa di gunakan dalam menangani masalah pengendalian (Controlling) dan peramalan (Prognosis)[10].

Terdapat beberapa tipe sistem yang dapat menggunakan teknik pelacakan dengan forward chaining yaitu:

1. Sistem yang diprepesentasikan dengan satu atau beberapa kondisi.

2. Pada setiap kondisi, sistem membuat beberapa rule berdasarkan beberapa knowledge base untuk rule - rule yang saling berkorespondensi dengan kondisi sebelumnya dari bagian if.

3. Setiap rule bisa menghasilkan kondisi baru dari konklusi yang diminta ke bagian then. Kondisi baru ini dapat ditambahkan pada kondisi lain yang sudah ada.

4. Setiap kondisi yang ditambahkan pada sistem akan diproses, dan jika ditemui suatu kondisi maka sistem akan kembali ke langkah 2 untuk mencari rules dalam knowledge base kembali dan jika tidak ada konklusi baru, sesi ini akan berakhir.

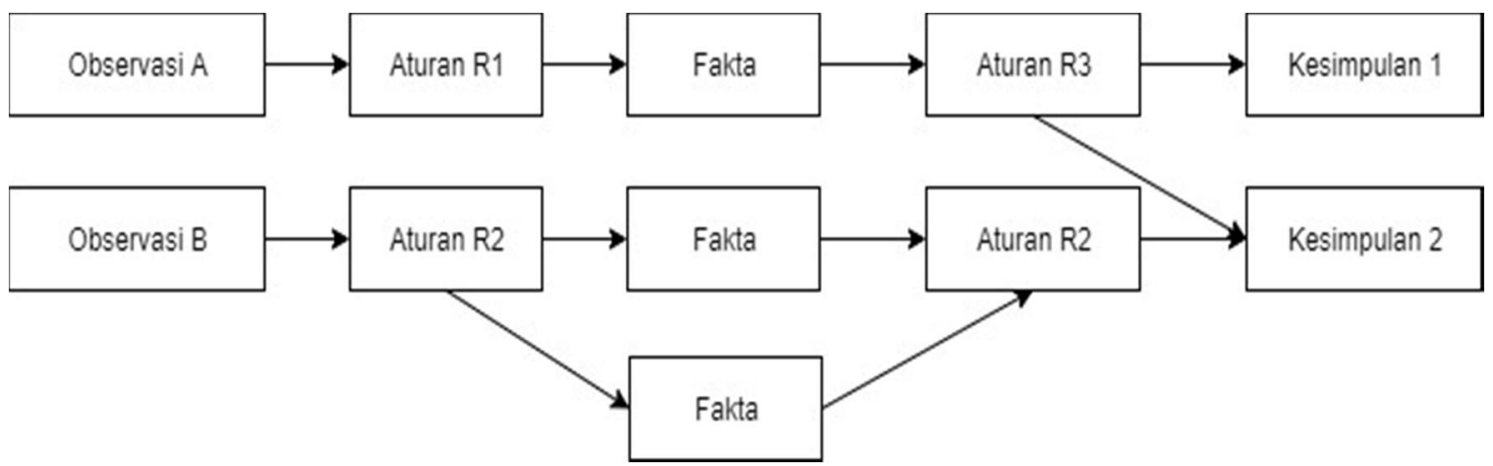

Gambar 2. Metode Forward Chaining [13] 


\subsection{Metode}

Metode penelitian yang digunakan dalam penelitian ini adalah metode penelitian kualitatif. Metode kualitatif adalah suatu pendekatan yang focus kepada pengamatan yang mendalam sehingga disebut pendekatan investigasi. Pengumpulan data dilakukan dengan cara langsung ke lokasi penelitian dan bertatap muka langsung serta berinteraksi dengan orang-orang ditempat penelitian.

1. Sumber Data

Sumber data diperoleh penulis secara langsung dari Kelompok Peneliti (KELTI) Proteksi

Tanaman Padi berupa data sekunder dan data primer.

2. Metode pengumpulan data menurut sumbernya, terbagi menjadi:

a. Data Primer

Dalam hal ini Bagian Kelti Proteksi BB Padi memberikan data penyakit kepada penulis untuk kemudian didiskusikan bersama untuk menjadi sebuah data penyakit dan gejala yang bisa diimplementasikan kedalam sebuah sistem.

b. Data Sekunder

"Data sekunder adalah sumber data yang diperoleh dengan cara membaca, mempelajari dan memahai melalui media lain yang bersumber dari literatur, buku-buku, serta dokumen" [11]

3. Kerangka pemikiran

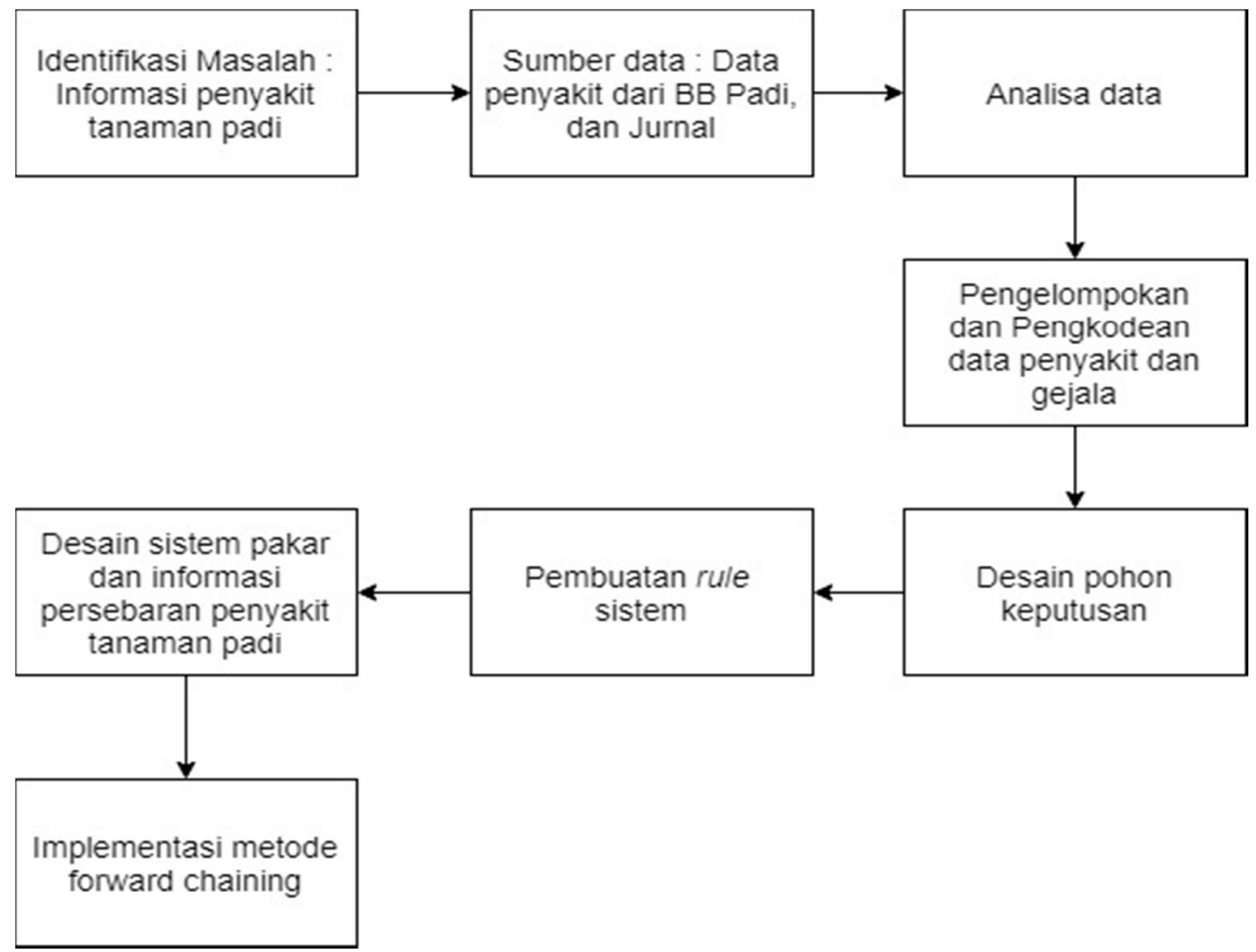

Gambar 3. Kerangka pemikiran 
4. Perencanaan sistem

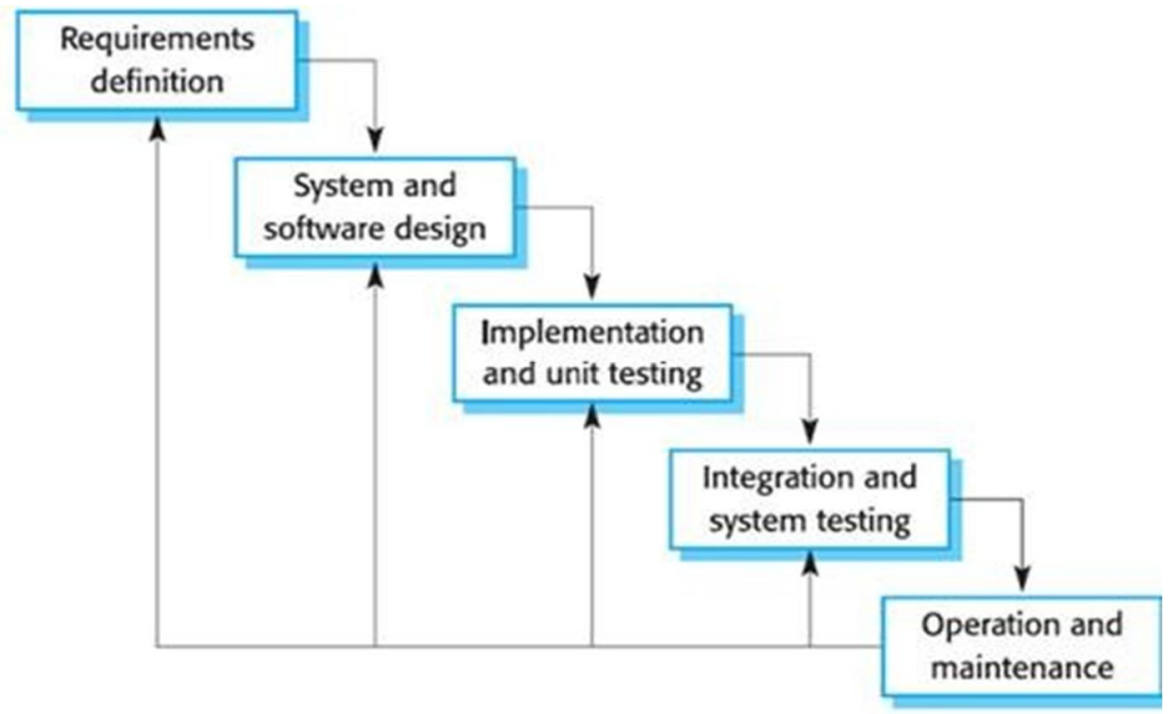

Gambar 4 Metode Waterfall [12]

Penggunaan Metode Waterfall pada perancangan sistem ini memiliki tahapan-tahapan sebagai berikut [12].

1. Requirements analysis and definition

2. System and software design

3. Implementation and unit testing

4. Operation and maintenance

\section{HASIL DAN PEMBAHASAN}

Hasil dar penelitian yang telah dilakukan adalah mendapatkan variabel masukan berupa kode gejala, variabel keluaran yaitu kode penyakit yang akan digunakan dalam menghasilkan diagnosa jenis penyakit, persebaran penyakit, cara pengendalian penyakit pada padi dan informasi persebaran penyakit tanaman padi, hal tersebut dapat dilihat pada tabel dibawah ini:

1. Tabel Analisis penyakit dan gejala

Tabel-tabel dibawah merupakan pengelompokan informasi gejala dan nama penyakit yang diberi label berupa kode-kode untuk diimplementasikan pada sistem.

a. Bagian Malai

Tabel 1. Bagian Malai

\begin{tabular}{|l|l|c|c|}
\hline Kode & \multicolumn{1}{|c|}{ Gejala } & Nama Penyakit & $\begin{array}{c}\text { Kode } \\
\text { Penyakit }\end{array}$ \\
\hline G8 & $\begin{array}{l}\text { Infeksi pada malai/leher berwarna abu- } \\
\text { abu }\end{array}$ & Blas (Blast) & P3 \\
\hline G18 & Tidak membentuk malai & Kerdil Rumput (Grassy & P6-1 \\
\cline { 1 - 2 } G16 & Hanya sedikit membentuk malai & P6-2 \\
\hline G24 & Malai Hampa & $\begin{array}{c}\text { Kerdil Hampa (Ragged } \\
\text { Stunt) }\end{array}$ & P7 \\
\hline
\end{tabular}

Rodianti' et., al [Implementasi Forward Chaining pada Sistem Pakar Sebagai Basis Informasi Persebaran Penyakit Padi 
b. Bagian Daun

Tabel 2. Bagian Daun

\begin{tabular}{|c|c|c|c|}
\hline Kode & Gejala & $\begin{array}{c}\text { Nama } \\
\text { Penyakit }\end{array}$ & $\begin{array}{c}\text { Kode } \\
\text { Penyakit }\end{array}$ \\
\hline G1 & $\begin{array}{l}\text { Gejala berwana putih kecoklatan memanjang seperti } \\
\text { mengering pada bagian tepi daun }\end{array}$ & \multirow{2}{*}{$\begin{array}{c}\text { Hawar Daun } \\
\text { Bakteri } \\
\text { (Bacterial } \\
\text { Leaf Blight) }\end{array}$} & $\mathrm{P} 1$ \\
\hline G2 & $\begin{array}{l}\text { Pada pagi hari, dapat ditemukan cairan bakteri terlihat } \\
\text { seperti butiran air pasa bagian terinfeksi. }\end{array}$ & & $\mathrm{P} 1$ \\
\hline G3 & $\begin{array}{l}\text { Gejala terlihat seperti anak panah terdapat di antara } \\
\text { urat daun }\end{array}$ & \multirow{3}{*}{$\begin{array}{c}\text { Bakteri Daun } \\
\text { Bergaris } \\
\text { (Bacterial } \\
\text { Leaf Streak) }\end{array}$} & $\mathrm{P} 2$ \\
\hline G4 & Berwarna kuning kecoklatan & & $\mathrm{P} 2$ \\
\hline G5 & $\begin{array}{l}\text { Luka pada daun terlihat transparan bila dihadapkan } \\
\text { cahaya matahari }\end{array}$ & & $\mathrm{P} 2$ \\
\hline G6 & Gejala berbentuk belah ketupat & \multirow[b]{2}{*}{ Blas (Blast) } & $\mathrm{P} 3$ \\
\hline G7 & $\begin{array}{l}\text { Bagian tengah berwarna abu-abu atau berwarna putih } \\
\text { dengan bagian tepi berwarna kecoklatan }\end{array}$ & & $\mathrm{P} 3$ \\
\hline G11 & $\begin{array}{l}\text { Gejala pada daun terlihat bercak tidak teratur, bagian } \\
\text { tepi berwarna coklat atau jingga }\end{array}$ & $\begin{array}{l}\text { Hawar } \\
\text { Pelepah } \\
\text { (Sheath } \\
\text { Blight) }\end{array}$ & P4 \\
\hline G13 & $\begin{array}{l}\text { Tanaman kerdil dan Gejala pada daun terjadi } \\
\text { perubahan warna dari hijau menjadi jingga atau } \\
\text { kemerahan }\end{array}$ & Tungro & P5 \\
\hline G17 & Ujung daunnya melintir & $\begin{array}{l}\text { Kerdil Hampa } \\
\quad \text { (Ragged } \\
\text { Stunt })\end{array}$ & P7 \\
\hline G19 & Daun berwarna kuning & $\begin{array}{c}\text { Kerdil } \\
\text { Rumput } \\
\text { (Grassy } \\
\text { Stunt) }\end{array}$ & P6-2 \\
\hline
\end{tabular}

c. Bagian Batang

Tabel 3. Bagian Batang

\begin{tabular}{|c|c|c|c|}
\hline Kode & Gejala & $\begin{array}{c}\text { Nama } \\
\text { Penyakit }\end{array}$ & $\begin{array}{c}\text { Kode } \\
\text { Penyakit }\end{array}$ \\
\hline G9 & Pada pelepah berwarna coklat keabuan & \multirow{2}{*}{$\begin{array}{l}\text { Hawar } \\
\text { Pelepah } \\
\text { (Sheath } \\
\text { Blight) }\end{array}$} & \multirow[b]{2}{*}{ P4 } \\
\hline G10 & $\begin{array}{l}\text { Bercak berbentuk elips/oval dan bentuk tidak teratur. } \\
\text { Warna hijau keabuan dan bagian tepi berwarna coklat } \\
\text { (seperti panu) }\end{array}$ & & \\
\hline G12 & Tanaman kerdil & \multirow{5}{*}{$\begin{array}{c}\text { Kerdil } \\
\text { Rumput } \\
\text { (Grassy Stunt) }\end{array}$} & \multirow{3}{*}{ P6-1 } \\
\hline G15 & Jumlah anakan banyak & & \\
\hline G22 & Batang tidak mengalami pembengkakan & & \\
\hline G14 & Batang mengalami pembengkakan & & \multirow{2}{*}{ P6-2 } \\
\hline G21 & Jumlah anakan normal & & \\
\hline G12 & Tanaman kerdil & \multirow{3}{*}{$\begin{array}{l}\text { Kerdil Hampa } \\
\quad \text { (Ragged } \\
\text { Stunt })\end{array}$} & \multirow{3}{*}{ P7 } \\
\hline G14 & Batang tidak mengalami pembengkakan & & \\
\hline G23 & Jumlah anakan sedikit & & \\
\hline
\end{tabular}

2. Pohon Keputusan 
Karena Tabel analisis gejala dan penyakit dibagi menjadi 3 maka pohon keputusan juga terbagi menjadi 3 bagian, yaitu: Bagian Malai, Daun dan Batang. Pada pohon keputusan menggambarkan alur variabel input berupa kode gejala-gejala yang terjadi dan akan menghasilkan variabel output berupa kode penyakit

a. Bagian Malai

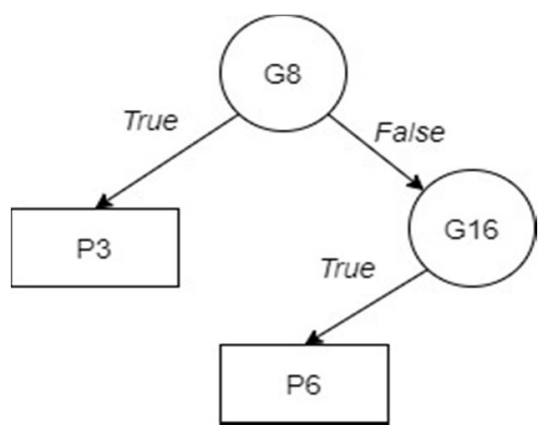

Gambar 5. Bagian Malai

b. Bagian Daun

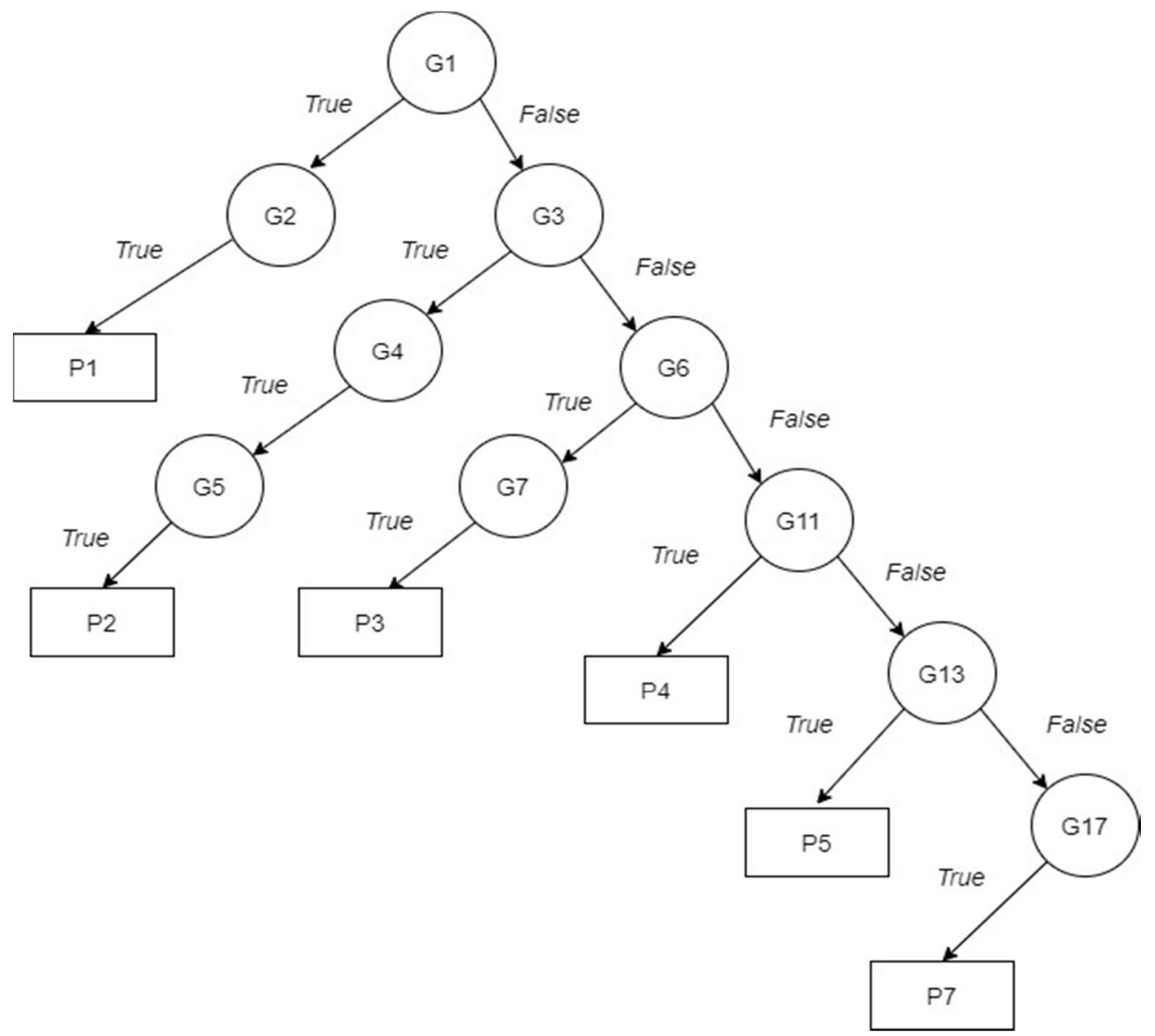

Gambar 6. Bagian Daun 
c. Bagian Batang

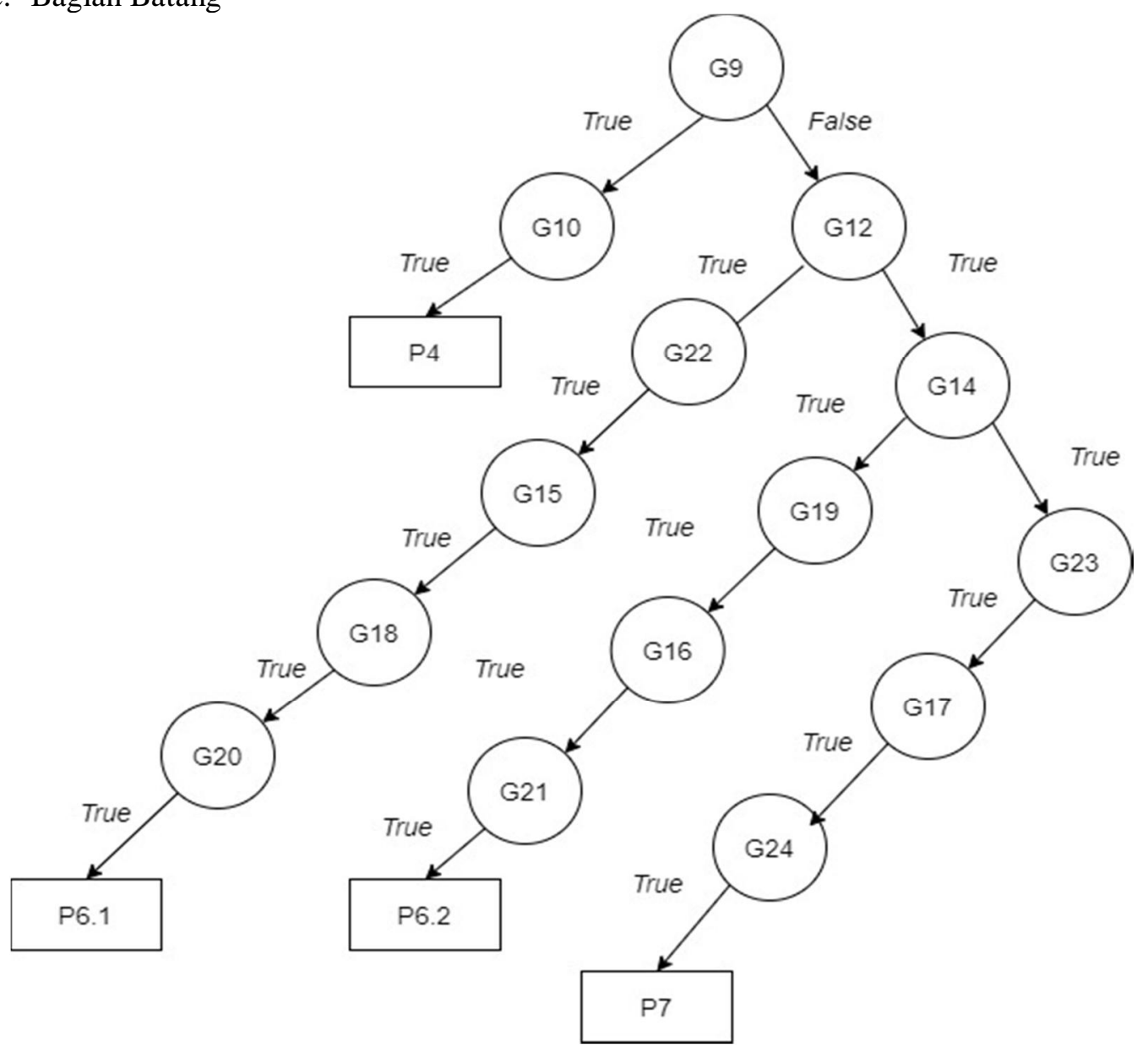

Gambar 7. Bagian Batang

3. Perancangan Sistem

Perancangan system dilakukan dengan terlebih dahulu membuat model dari sistemnya. Model di buat menggunakan prinsip pemodelan berorientasi objek dengan pemodelan Unified Modelling Language (UML). Pemodelan ini terdiri dari komponen - komponen berikut:

a. Use Case Diagram

Use Case diagram adalah penggambaran perilaku actor di dalam sistem yang di buat. Sistem pendukung keputusan ini memiliki 2 aktor yaitu admin dan pengguna yang dapat di lihat pada gambar 6 berikut: 


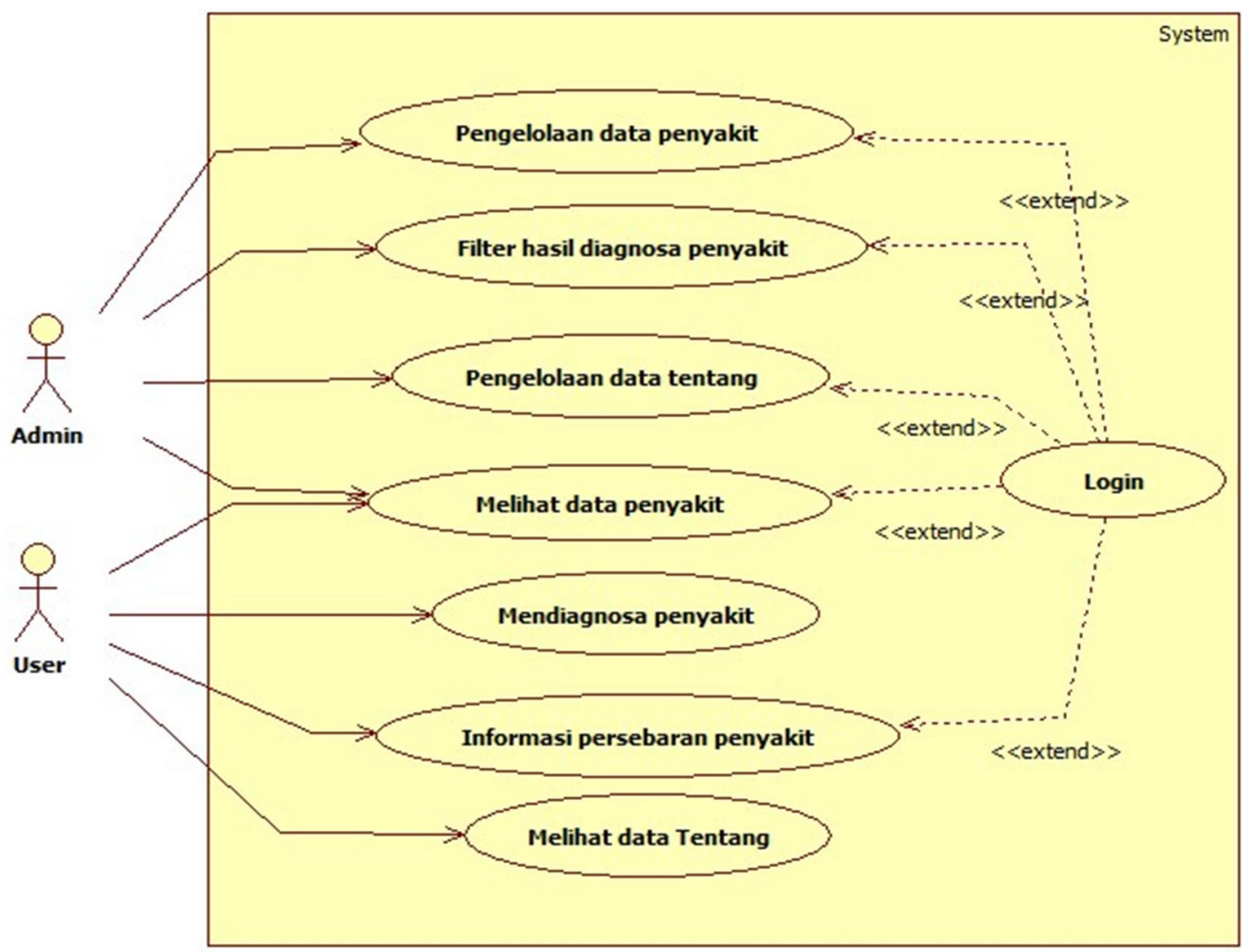

Gambar 8. Use Case Diagram

b. Struktur Proses

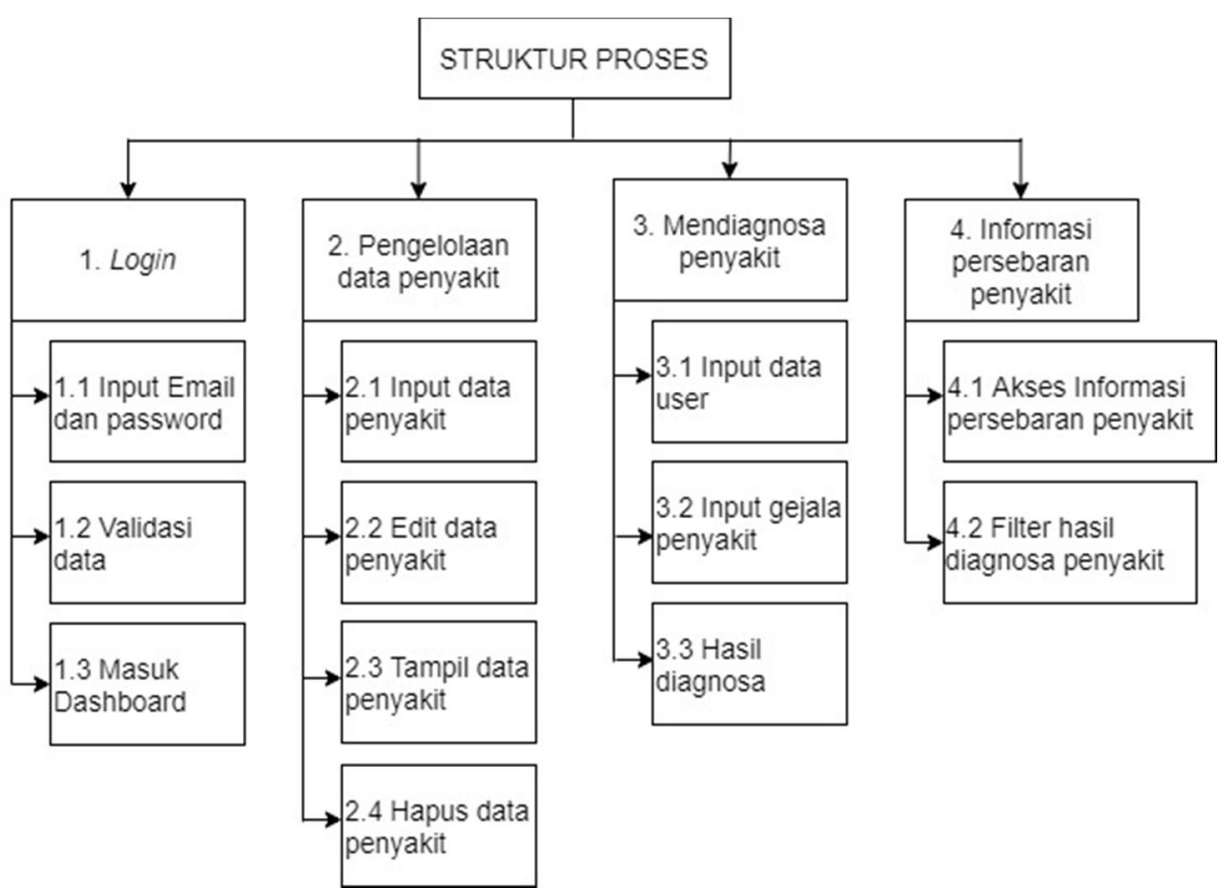

Gambar 9. Sruktur Proses

Rodianti' et., al [Implementasi Forward Chaining pada Sistem Pakar Sebagai Basis Informasi Persebaran Penyakit Padi 
c. Diagram Konteks

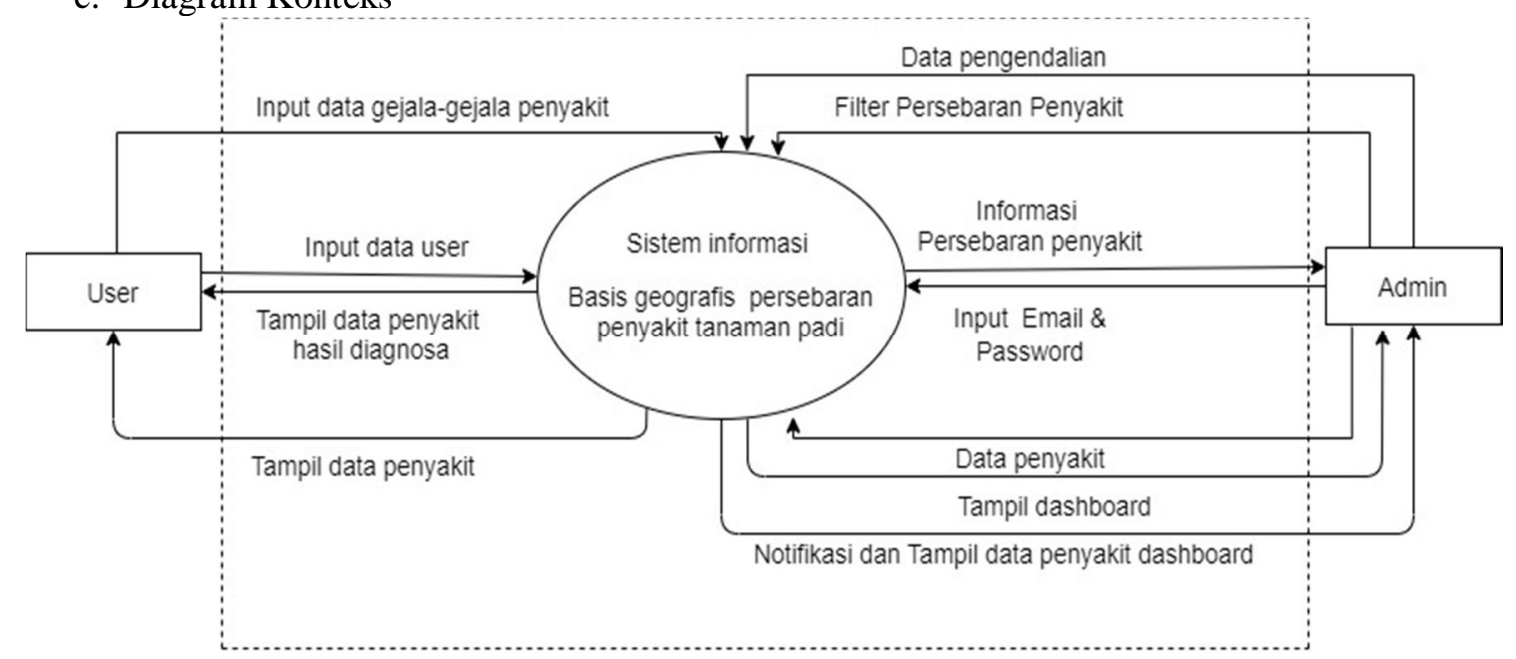

Gambar 10. Diagram Konteks

d. Flowchart sistem pakar untuk mendiagnosa penyakit tanaman padi

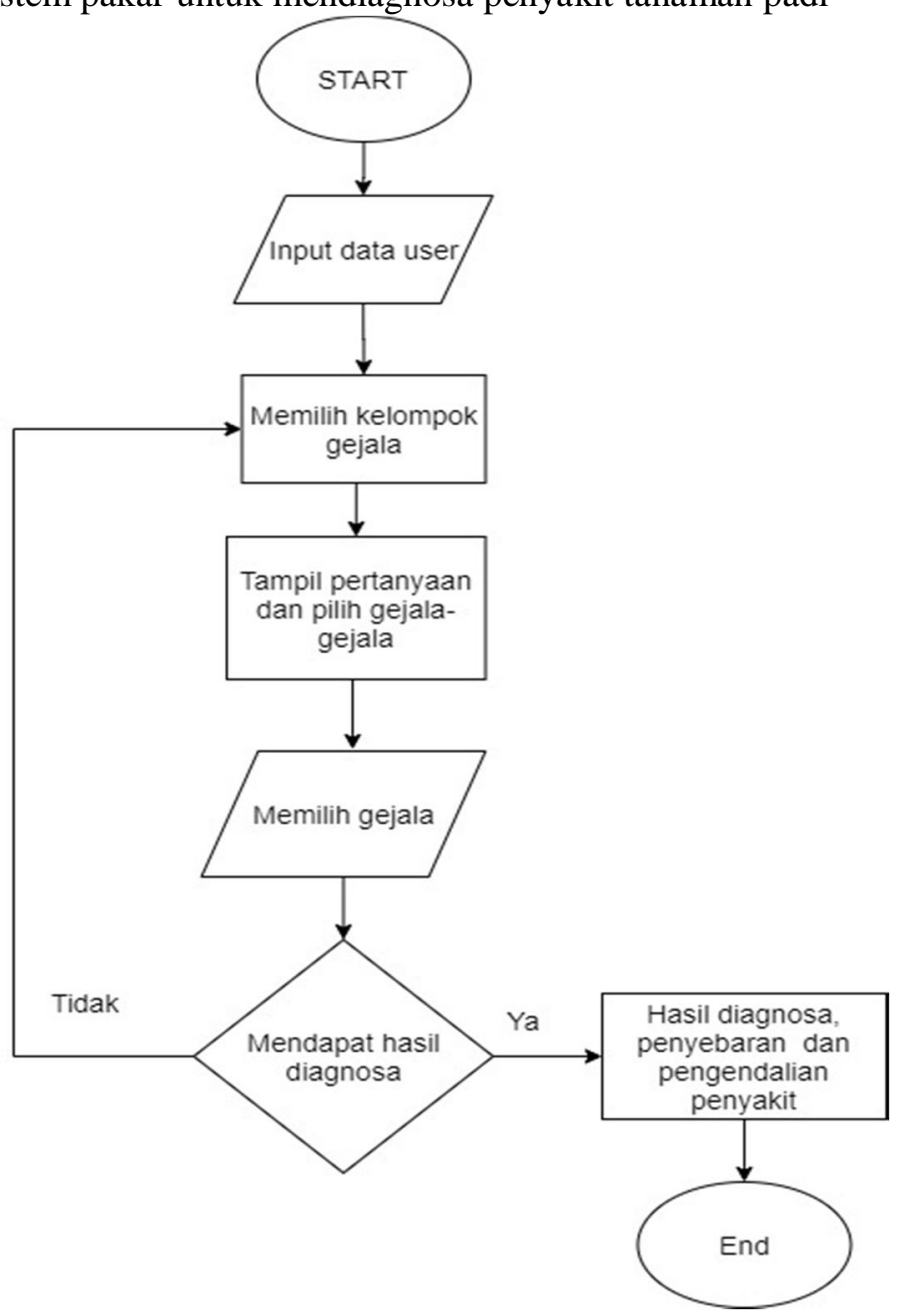

Gambar 11. Flowchart Sistem Pakar Diagnosa Penyakit Tanaman Padi

Rodianti' et., al [Implementasi Forward Chaining pada Sistem Pakar Sebagai Basis Informasi Persebaran Penyakit Padi 


\section{Implementasi}

Hasil penelitian yang telah dilakukan menghasilkan suatu Web Apps diagnosa penyakit tanaman padi. Pengguna melakukan pemilihan gejala-gejala yang terjadi untuk kemudian mendapatkan kesimpulan berupa foto penyakit, nama penyakit, penyebab, cara penyebaran penyakit, pengendalian selain itu juga pengguna akan melihat beberapa lokasi persebaran penyakit dan untuk admin akan mengetahui keseluruhan data persebaran penyakit melalui google maps.

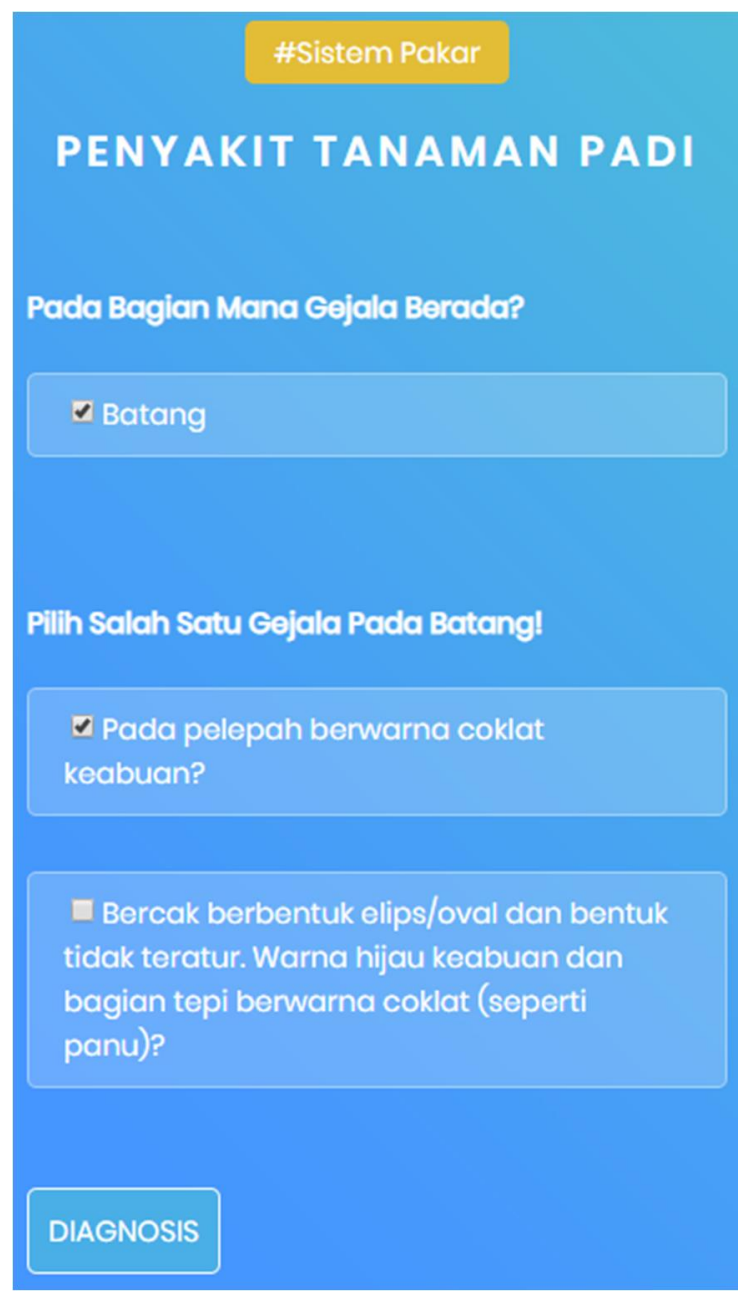

Gambar 12. Diagnosa Penyakit

Ditularkan oleh Nilaparvata lugens. Virus bersifat persisten pada vektor. Penyakit tidak ditularkan oleh benih Selengkapnya

Kerdil Rumput (Grassy Stunt) Tipe 2 Universitas Islam Nusantara, Legon Kulon, Subang, Jawa Barat

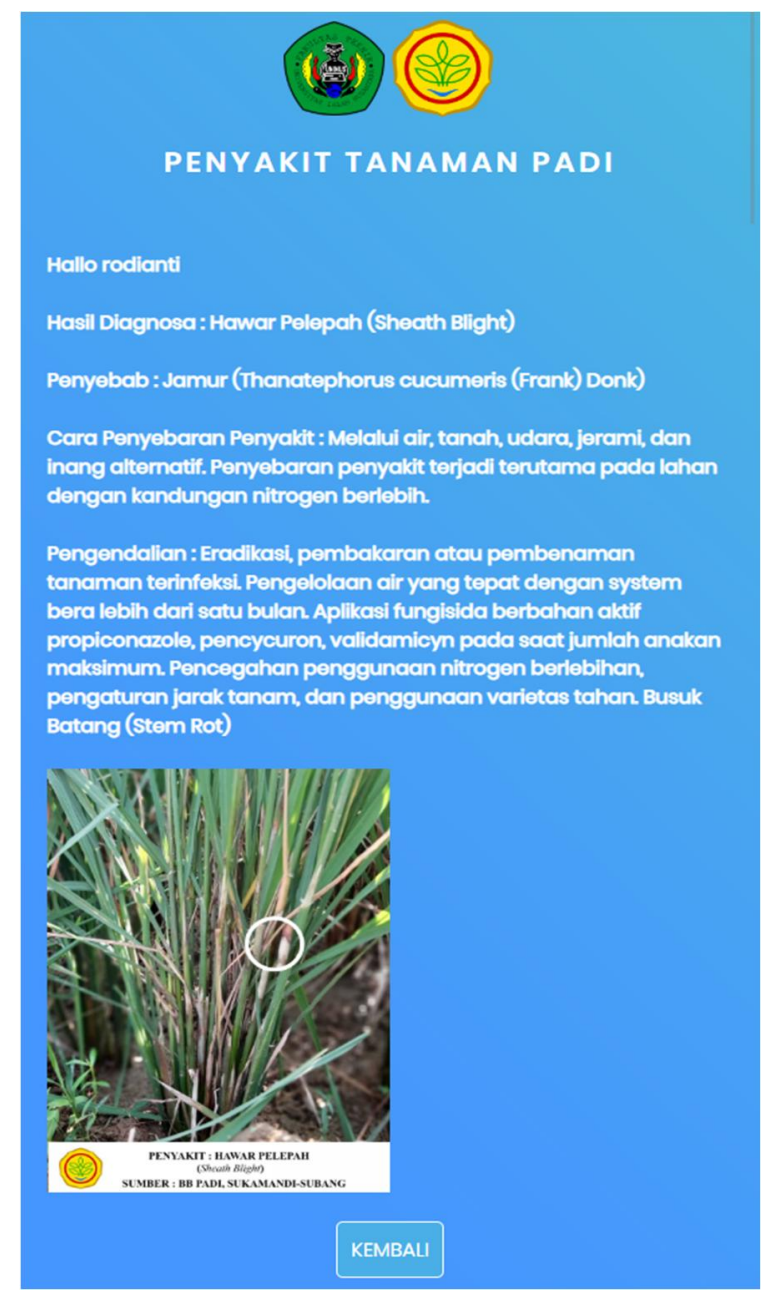

Gambar 13. Hasil Diagnosa

Ditularkan oleh Nilaparvata lugens. Virus bersifat persisten pada vektor. Penyakit tidak ditularkan oleh benih Selengkapnya

Kerdil Rumput (Grassy Stunt) Tipe 2 Universitas Islam Nusantara, Pabuaran, Subang, Jawa Barat

26 Feb 20, $10: 02$ am

Gambar 14. Hasil Diagnosa

Rodianti' et., al [Implementasi Forward Chaining pada Sistem Pakar Sebagai Basis Informasi Persebaran Penyakit 


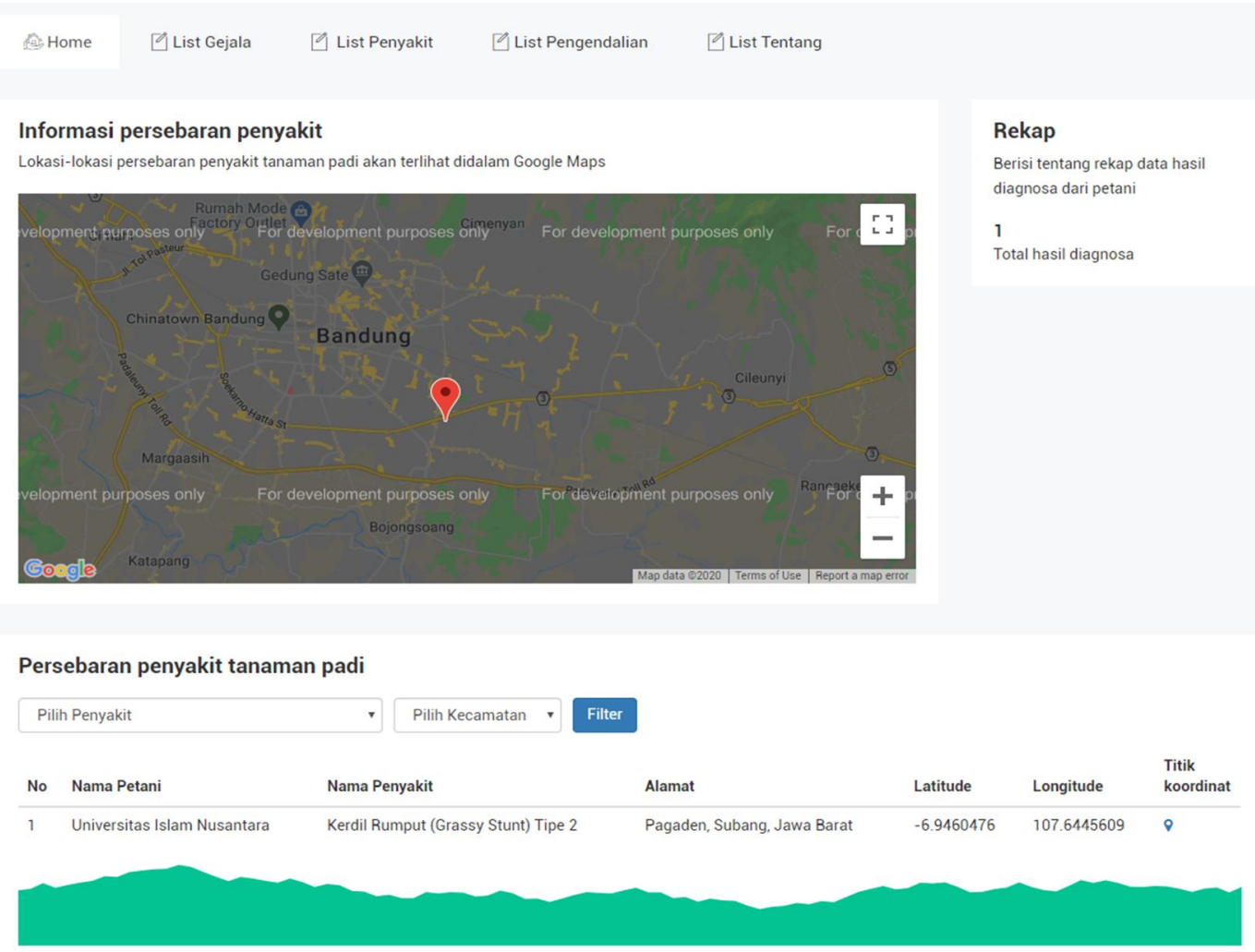

Gambar 15. Halaman Admin

\section{Pengujian}

Pengujian akurasi ini dimaksudkan untuk membandingkan antara hasil pada sistem dengan hasil diagnosa oleh pakar. Menggunakan hasil diagnosa 8 data, didapatkan bahwa hasil diagnosa, didapatkan bahwa sistem dengan pakar adalah sama, maka selanjutnya akan menghitung nilai akurasi dengan persamaan antara pengujian sistem dan pengujian yang dilakukan oleh pakar sebagai berikut:

$$
\begin{aligned}
\text { Nilai Akurasi } & =\frac{\text { Jumlah data akurasi }}{\text { Keseluruhan data }} \times 100 \% \\
\text { Nilai Akurasi } & =\frac{8}{8} \times 100 \%
\end{aligned}
$$

\section{KESIMPULAN}

Hasil analisis dan pengujian yang telah dilakukan mengenai implementasi metode forward chaining pada sistem pakar sebagai basis informasi geografis persebaran tanaman padi, mendapatkan kesimpulan beberapa hal diantaranya adalah: Penelitian yang telah dilakukan menghasilkan sebuah perangkat lunak (Software) tentang sistem pakar penyakit tanaman padi berbasis Web Apps, sistem pakar mampu mendiagnosa penyakit tanaman padi berdasarkan gejala-gejala penyakit kemudian akan menghasilkan diagnosa berupa penyakit, penyebaran penyakit dan cara pengendalian penyakit. 
Sistem pakar pada penelitian ini memiliki nilai lebih yaitu setelah menginputkan gejala dan mengetahui jenis penyakit maka akan mengetahui lokasi input pengguna saat ini. Pada menu dashboard admin akan menampilkan informasi persebaran penyakit tanaman padi dalam tampilan google maps. Dari sisi pengguna, sistem akan menampilkan beberapa list hasil diagnosa dan lokasi beberapa pengguna terakhir input. Nilai akurasi sebesar $100 \%$ hasil dari testing sistem yang dilakukan oleh beberapa pakar (expert) penyakit tanaman padi.

\section{SARAN}

Saran untuk penelitian selanjutnya: Tidak mengisi lokasi secara manual, akan tetapi Convert dari koordinat yang sudah di ambil menggunakan Reverse geocoding. Agar tidak hanya lingkup petani Kabupaten subang saja yang bisa menggunakan tapi petani seluruh indonesia. Kemudian menampilkan foto setiap gejala yang ada agar pengguna mudah memahami gejala yang dimaksudkan dan diharapkan kedepannya bisa dibuat aplikasi android sistem pakar agar lebih mudah digunakan oleh pengguna.

\section{UCAPAN TERIMA KASIH}

Terimakasih kepada Allah SWT yang telah memberikan karunia-Nya kepada penulis sehinggga penulis dapat menyelesakan jurnal ini. Penulis juga mengucapkan banyak terimakasih kepada keluarga, civitas akademik Universitas Islam Nusantara terutama Fakultas Teknik Prodi Teknik Informatika, Dosen pembimbing dan Kelompok peneliti (KELTI) Proteksi tanaman padi di BALAI Besar Penelitian Padi (BB Padi) Sukamandi yang sudah memberikan dukungan kepada penulis.

\section{DAFTAR PUSTAKA}

[1] M. N. Nadziroh, "Peran Sektor Pertanian Dalam Pertumbuhan Ekonomi di Kabupaten Magelang," J. AGRISTAN, Vol. 2, No. 1, pp. 52-60, 2020.

[2] F. Pertanian, U. Jabal, and F. P. Unsyiah, "Pertumbuhan dan Hasil Padi (Oryza sativa L.) Akibat Pemberian Arang Aktif dan Urea," J. Manaj. Sumberd. Lahan, vol. 1, no. 2, pp. 146-150, 2012.

[3] A. Saepulloh and D. D. S. Fatimah, "Pengembangan Sistem Pakar Diagnosis Penyakit dan Hama pada Tanaman Padi Varietas Sarinah Berbasis Android," J. Algoritm., Vol. 13, No. 1, pp. 149-156, 2016, doi: 10.33364/algoritma/v.13-1.149.

[4] K. M. Wibowo, I. Kanedi, and J. Jumadi, "Sistem Informasi Geografis (SIG) Menentukan Lokasi Pertambangan Batu Bara di Provinsi Bengkulu Berbasis Website," J. Media Infotama, Vol. 11, No. 1, pp. 51-60, 2015.

[5] D. Rosadi and I. Sidharta, "Model Perancangan Sistem Informasi Dalam Mendukung Ketahanan Pangan,” Bisnis dan Iptek, Vol. 9, pp. 17-27, 2016. 
[6] R. Rizky, M. Ridwan, and Z. Hakim, "Implementasi Metode Forward Chaining Untuk Diagnosa Penyakit Covid 19 di RSUD Berkah Pandeglang Banten,” J. Teknol. Inf., Vol. 4, No. 1, pp. 1-4, 2020.

[7] I. R. Yansyah and S. Sumijan, "Sistem Pakar Metode Forward Chaining Untuk Mengukur Keparahan Penyakit Gigi dan Mulut," J. Sistim Inf. dan Teknol., Vol. 3, pp. 41-47, 2020, doi: 10.37034/jsisfotek.v3i2.103.

[8] A. F. Setiawan and A. K. Agung, "Antivirus: Jurnal Ilmiah dan Teknik Informatika, November 2016, Vol.10, No. 2 50,” J. Antivirus, Vol. 10, No. ISSN: 1978-5232, pp. 50$55,2016$.

[9] A. V. Pakpahan et al., "Sistem Pakar Untuk Tumbuh Kembang Anak Menggunakan Metode Forward Chaining," Simetris J. Tek. Mesin, Elektro dan Ilmu Komput., Vol. 3, No. 1, pp. 817-824, 2018.

[10] Y. Apridiansyah, N. D. M. Veronika, and R. Oktarini, "Desain dan Implementasi Sistem Pakar Untuk Menentukan Tipe Autisme pada Anak Usia 4-6 Tahun Dengan Metode Forward Chaining," Pseudocode, Vol. 4, No. 2, pp. 97-104, 2017, doi: 10.33369/pseudocode.4.2.97-104.

[11] A. Febriansyah, "Tinjauan Atas Proses Penyusunan Laporan Keuangan pada Young Enterpreneur Academy Indonesia Bandung," J. Ris. Akunt., Vol. 8, No. 2, 2017, doi: 10.34010/jra.v8i2.525.

[12] G. Wiro Sasmito, "Penerapan Metode Waterfall pada Desain Sistem Informasi Geografis Industri Kabupaten Tegal,” J. Inform. Pengemb. IT, Vol. 2, No. 1, pp. 6-12, 2017.

[13] W. Verina, "Penerapan Metode Forward Chaining Untuk Mendeteksi Penyakit THT," J. Tek. Inform. dan Sist. Inf., Vol. 1, No. 2, pp. 123-138, 2016.

[14] A. Kusnadi, "Perancangan Aplikasi Sistem Pakar Untuk Mendiagnosa Penyakit pada Manusia,” J. Ultim., Vol. 5, No. 1, pp. 1-8, 2013, doi: 10.31937/ti.v5i1.307. 